\title{
Synthesis of new substituted lactones by “click” chemistry
}

\author{
Raphaël Riva, Laila Chafaqi, Robert Jérôme*,and Philippe Lecomte \\ Center for Education and Research on Macromolecules (CERM) \\ University of Liège, Sart-Tilman, B6, 4000 Liège, Belgium \\ E-mail: rjerome@ulg.ac.be
}

\section{Dedicated to Professor Alain Krief on the occasion of his $65^{\text {th }}$ anniversary}

\begin{abstract}
Several new oxepan-2-ones substituted by an ester, an ammonium, a hydroxyl, an acrylate and a poly(ethylene oxide) chain, respectively, were synthesized by the Huisgen's [3+2] cycloaddition of duly substituted alkynes onto 5-azidooxepan-2-one $\mathbf{1 0 .}$
\end{abstract}

Keywords: Functional lactones, click reaction, cycloaddition, aliphatic polyester

\section{Introduction}

At the time being, a steadily increasing attention is paid to the ring-opening polymerization of lactones and lactides into biodegradable and biocompatible aliphatic polyesters as substitutes for non biodegradable material in environmental and biomedical applications. ${ }^{1}$ Among them, poly(oxepan-2-one), or poly( $\varepsilon$-caprolactone) (PCL), is commercialized by Solvay, Union Carbide and Daicel. ${ }^{2}$ Nevertheless, the lack of pendant functional groups along the chains is a severe limitation for many applications. In order to tackle this drawback, the usual strategy relies on the ring-opening polymerization of lactones, duly substituted by a functional group ${ }^{3,4}$, e.g., pendant unsaturation, ${ }^{5-7}$ alkyne, ${ }^{8}$ protected carboxylic acid, ${ }^{9}$ alcohol, ${ }^{10,11}$ diol, ${ }^{12}$ protected alcohol, ${ }^{9,13-15}$ protected diol, ${ }^{16}$ ketal, $^{17,18}$ ketone $^{19}$ and halogen ${ }^{20,21}$. Nevertheless, the synthesis of a new lactone requires a specific strategy. Moreover, the protection of the functional group prior to polymerization cannot systematically be avoided. ${ }^{22}$ Last but not least, multistep synthesis and touchy purification techniques can decrease the global yield and be a severe limitation for the production of new functional lactones.

In order to overcome these drawbacks, the more general strategy shown in Scheme 1 was considered, which relies on the synthesis of a wide range of lactones by derivatization of a single precursor by a variety of traditional reactions of organic chemistry. For being effective, this strategy has to fulfill the following criteria: (i) the synthesis of the first monomer must be as direct as possible, (ii) the derivatization reaction must be quantitative under very mild conditions 
in order to prevent detrimental ring-opening of the lactone from occurring, (iii) the reaction must tolerate the envisioned functional groups in order to avoid cumbersome protection/deprotection reactions, (iv) the purification of the final lactone must be as simple as possible at the multi-gram scale.
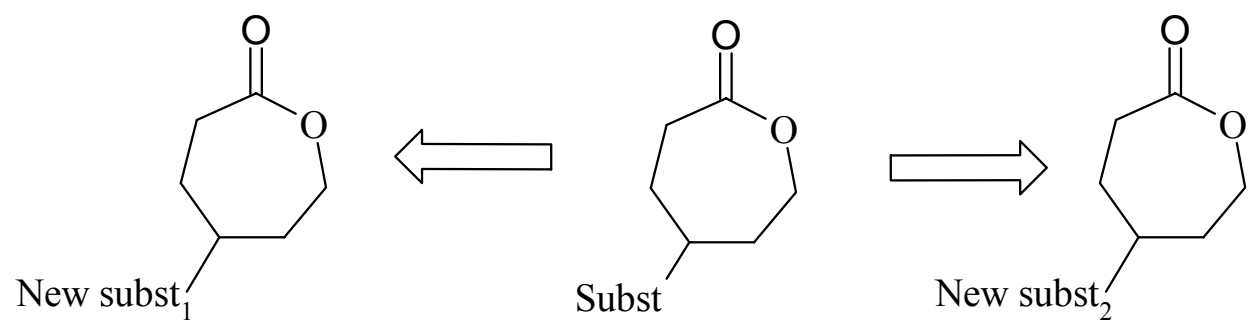

\section{Scheme 1}

The copper-mediated Huisgen's [3+2] cycloaddition, ${ }^{23}$ the "cream of the crop" of click reactions, ${ }^{24}$ turned out to be very beneficial. We previously reported on the successful cycloaddition of duly substituted low molecular weight or polymeric alkynes onto the pendant azide groups of PCL and poly(3,6-dimethyl-1,4-dioxane-2,5-dione) (poly(lactide) or PLA). ${ }^{3,25,26}$ This reaction was complete within short reaction times $(<2 \mathrm{~h})$. Moreover, when the reaction was carried out at $35^{\circ} \mathrm{C}$ in an organic medium (THF or DMF), no degradation of the polyester chains was observed, even in case of the hydrolytically unstable PLA. This success prompted us to investigate whether this "click" reaction could be effectively extended to azide-substituted lactones in line with Scheme 1.

\section{Results and Discussion}

The strategy that we first tested relied on the reaction of 3-chlorooxepan-2-one 1 with sodium azide, followed by the cycloaddition of a duly substituted alkyne (Scheme 2). As reported elsewhere, 3-chlorooxepan-2-one 1 can be very easily synthesized by the Baeyer-Villiger oxidation of 2-chlorocyclohexanone $2 .{ }^{27}$ Its reaction with sodium azide was complete at $45^{\circ} \mathrm{C}$ after $72 \mathrm{~h}$. The crude 3-azidooxepan-2-one 3 was reacted without further purification, with but-3yn-1-ol 4 in the presence of copper iodide (CuI) and triethylamine in THF at $35^{\circ} \mathrm{C}$. The reaction was monitored by IR spectroscopy, and the band at $2106 \mathrm{~cm}^{-1}$ disappeared completely after $2 \mathrm{~h}$, in agreement with the successful cycloaddition. Although the "click" was effective, the ${ }^{1} \mathrm{H}$ NMR spectrum (not shown) clearly indicated that the expected 3-[4-(2-hydroxyethyl)-1H-1,2,3-triazol1-yl]oxepan-2-one 5 did not accumulate in the reaction medium (yield $0 \%$ ) but rather the undesired ring-opened version. 


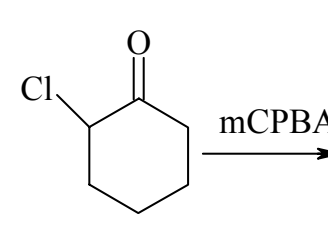

2<smiles>O=C1OCCCCC1Cl</smiles>

1

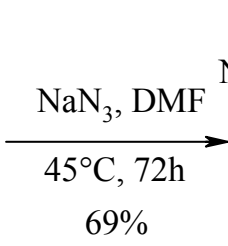

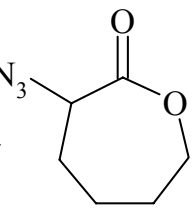

3

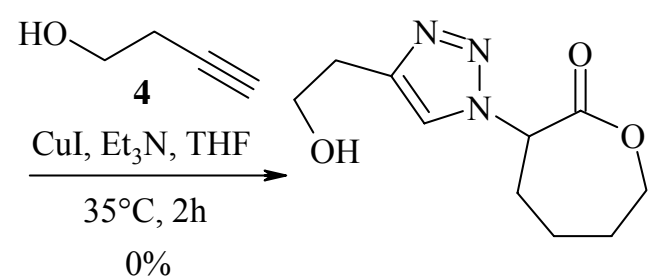

5

\section{Scheme 2}

The sensitivity of the lactone to ring-opening is thus increased by substitution in position 3 . Therefore, the strategy was modified by using the oxepan-2-one substituted in position 5 rather than in position 3, thus farther from the ester group. The three step synthesis of 5-bromooxepan2-one 6 was recently reported (Scheme 3): ${ }^{20}$ (i) reaction of 7-oxabicyclo[2.2.1]heptane 7 with hydrogen bromide, (ii) oxidation of 4-bromocyclohexanol 8 by pyridinium chlorochromate (PCC), (iii) Baeyer-Villiger oxidation of 4-bromocyclohexanone 9 with 3chlorobenzenecarboperoxoic acid (mCPBA). The global yield (50\%) was moderate because of the lower yield of the first step (60\%). However, the additional step for the synthesis of $\mathbf{6}$ was of a high yield, although 5-bromooxepan-2-one 6 was used as formed, thus without purification.

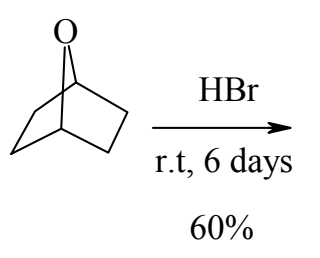

7

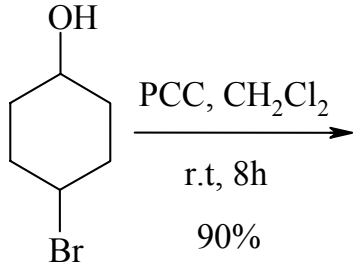

8<smiles>O=C1CCC(Br)CC1</smiles>

9

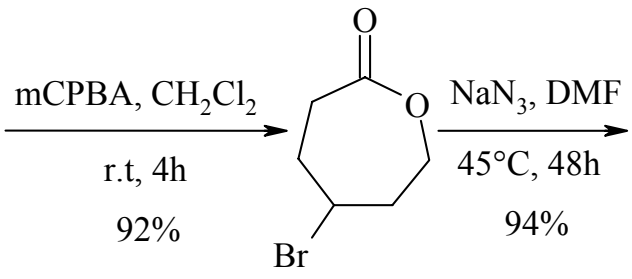

6

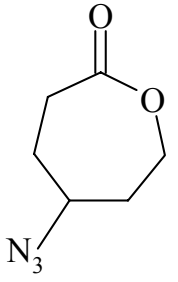

10

\section{Scheme 3}

Crude 5-bromooxepan-2-one 6 was reacted with sodium azide at $45^{\circ} \mathrm{C}$, and 5-azidooxepan-2one 10 was collected (94\%) after $48 \mathrm{~h}$. IR spectroscopy confirmed the appearance of an absorption at $2100 \mathrm{~cm}^{-1}$ typical of azide groups. ${ }^{1} \mathrm{H}$ NMR showed that the multiplet at $4.65 \mathrm{ppm}$ assigned to the $\mathrm{CH}-\mathrm{Br}$ proton disappeared and that a new multiplet was observed at $3.85 \mathrm{ppm}$ characteristic of the $\mathrm{CH}-\mathrm{N}_{3}$. 5-azidooxepan-2-one $\mathbf{1 0}$ and prop-2-yn-1-yl benzoate 11 were reacted at $35^{\circ} \mathrm{C}$ in the presence of $\mathrm{CuI}$ and $\mathrm{Et}_{3} \mathrm{~N}$. After $2 \mathrm{~h}$, the IR absorption at $2100 \mathrm{~cm}^{-1}$ disappeared, consistent with the apparent completion of the cycloaddition. [1-(7-oxooxepan-4yl)-1H-1,2,3-triazol-4-yl]methyl benzoate 12 was dissolved in DMF, purified by recrystallization (see experimental section), and analyzed by ${ }^{1} \mathrm{H}$ NMR. A singlet at $8.4 \mathrm{ppm}$ assigned to the proton of the triazole ring confirmed the success of the click reaction. In contrast to the polymeric version of $\mathbf{1 2}$, that showed only one resonance for the two $-\mathrm{CH}_{2}-\mathrm{O}-\mathrm{CO}$ - protons, two resonances at $4.45 \mathrm{ppm}$ and $4.30 \mathrm{ppm}$ were detected for the two non magnetically equivalent - 
$\mathrm{CH}_{2}$-O-CO- protons, which unambiguously proved that the lactone did not open during the "click" reaction. As a rule, lactone substituted in position 5 are less sensitive to ring-opening than lactones substituted in position 3, at least under the experimental conditions used in this work.

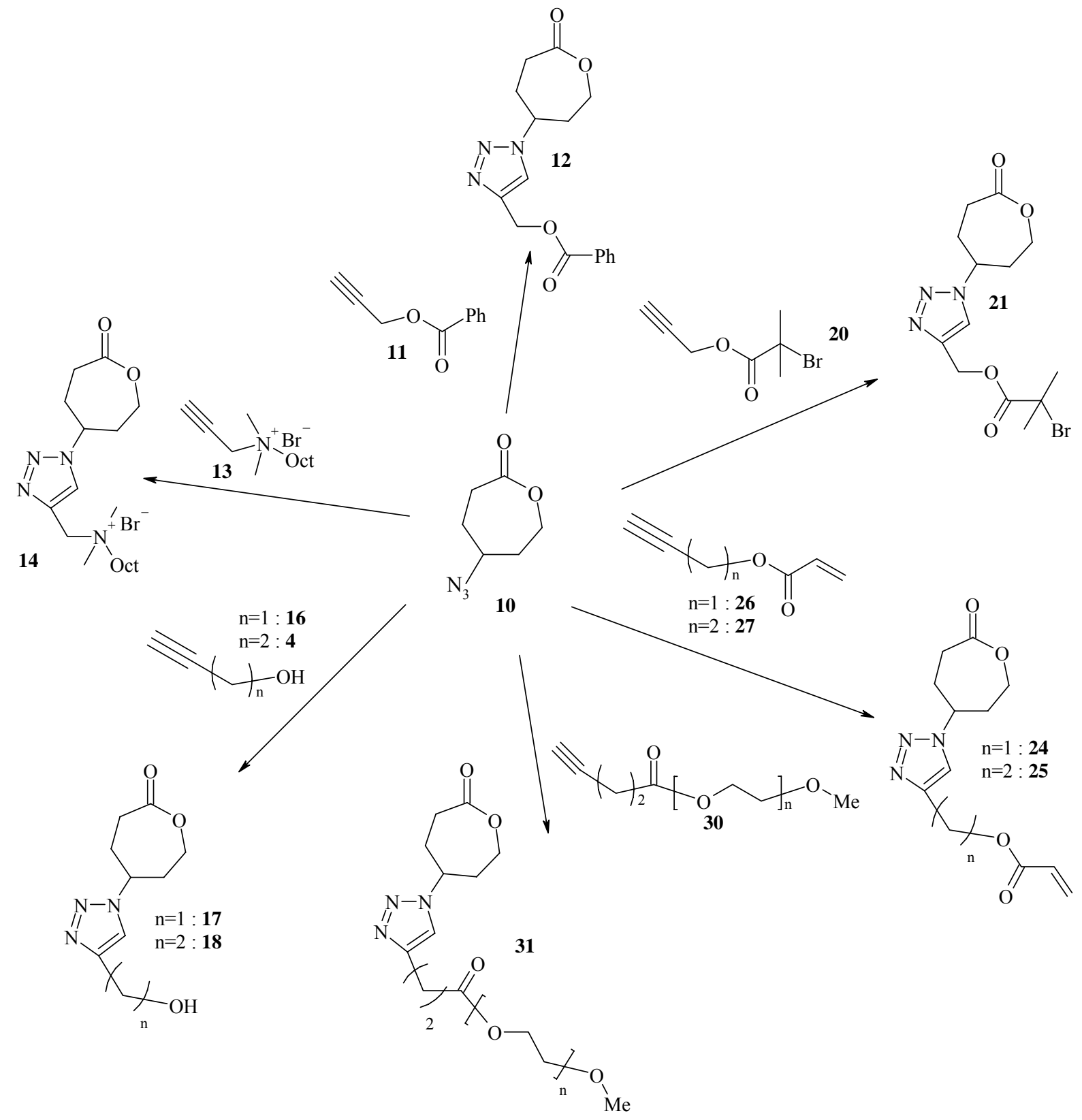

\section{Scheme 4}


The lactone $\mathbf{1 0}$ is a key derivative for the synthesis of a wide range of new functional lactones because of the variety of the structure of the alkyne that can be involved in the "click" reaction.

The click cycloaddition of $N, N$-dimethyl- $N$-prop-2-yn-1-yloctan-1-ammonium bromide 13 to 10 was a route to $N, N$-dimethyl- $N$ - $\{[1-(7-$ oxooxepan-4-yl)-1H-1,2,3-triazol-4-yl]methyloctan-1ammonium bromide 14, thus a lactone substituted by a cationic group, whose the polymerization will make hydrosoluble biodegradable polyester available. Moreover, this type of polymer has potential in different applications, such as gene therapy, antimicrobial materials and biodegradable surfactants.

A lactone with a hydroxyl substituent is nothing but an "inimer", quite similar to 5-(2hydroxyethyl)oxepan-2-one 15 that was synthesized by Fréchet et al. and polymerized in the presence of tin octanoate with formation of hyperbranched copolyesters (Scheme 5). ${ }^{10}$

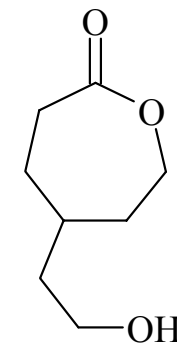

15

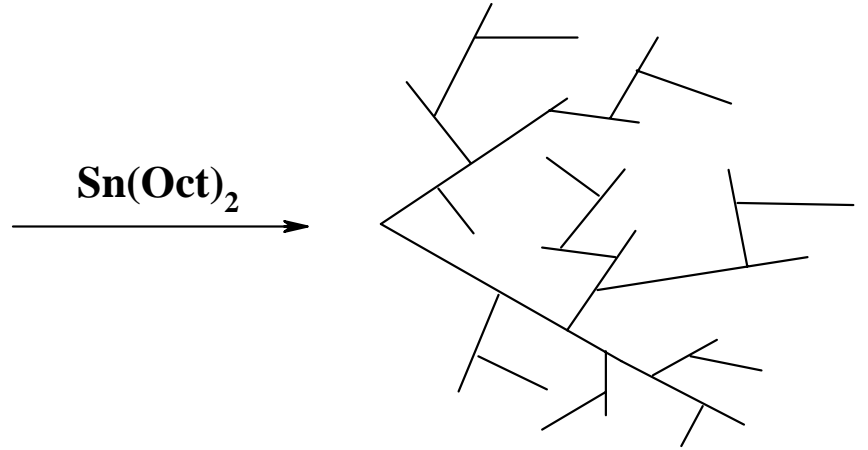

hyperbranched polyester

\section{Scheme 5}

Prop-2-yn-1-ol 16 and but-3-yn-1-ol 4 were reacted with 5-azidooxepan-2-one 10 under the usual conditions for the Huisgen's [3+2] cycloaddition, so leading to 5-[4-(hydroxymethyl)-1H1,2,3-triazol-1-yl]oxepan-2-one 17 and 5-[4-(hydroxyethyl)-1H-1,2,3-triazol-1-yl]oxepan-2-one 18, respectively (Scheme 4). Remarkably, no protection/deprotection of the hydroxyl group was required and the lactone was not ring-opened, as confirmed by ${ }^{1} \mathrm{H}$ NMR spectroscopy (see the experimental part).

Hedrick et al. synthesized an asymmetric inimer, 7-oxooxepan-4-yl 2-bromo-2methylpropanoate 19, prone to ring-opening polymerization and to initiation of atom transfer radical polymerization (ATRP) (Scheme 6). ${ }^{21}$ Initiation of ATRP by this inimer yielded a macromonomer that was ring-opening polymerized with formation of the parent graft copolymer. The sequence of reactions was reversed. The ring-opening polymerization of 19 into polyester chains with pendant ATRP initiators, was followed by ATRP as an alternative route to the aforementioned graft copolymers. Remarkably, the experimental conditions used for ATRP and 
ROP were compatible, such that the "one-pot" implementation of ROP and ATRP was successful. ${ }^{21}$

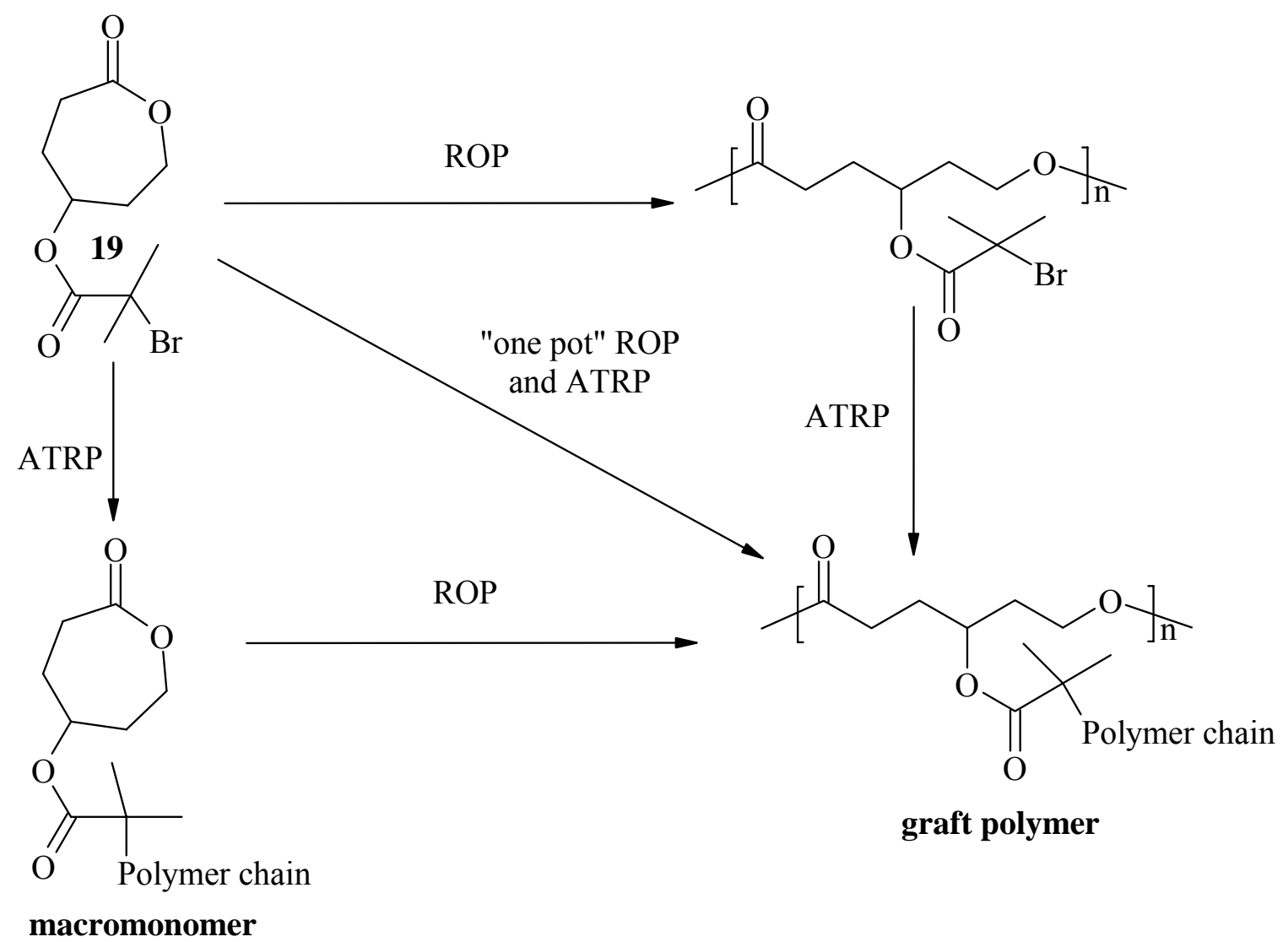

\section{Scheme 6}

Nevertheless, 5-bromooxepan-2-one 6 used in this work was unable to initiate ATRP and was merely a monomer rather than an inimer. "Click" chemistry was used to convert the bromide group of 5-bromooxepan-2-one 6 into a bromoisobutyrate, known as an initiator of ATRP. ${ }^{26}$ For this purpose, 5-azidooxepan-2-one $\mathbf{1 0}$ was reacted with prop-2-yn-1-yl 2-bromo-2methylpropanoate 20 and [1-(7-oxooxepan-4-yl)-1H-1,2,3-triazol-4-yl]methyl 2-bromo-2methylpropanoate 21 was formed in high yield (Scheme 4).

Synthesis of aliphatic polyesters with pendant acrylates is highly desirable for making them cross-linkable and appropriate precursors of biodegradable networks. ${ }^{5,26}$ Moreover, strategies for the production of nanoparticles ${ }^{28}$ and macrocyclic polyesters ${ }^{29}$ rely on the intramolecular crosslinking of pendant acrylates. Until now, acrylates substituted aliphatic polyesters were synthesized by ring-opening polymerization of 7-oxooxepan-4-yl acrylate 22 and 1-(2oxooxepan-3-yl)ethyl acrylate $\mathbf{2 3}$, respectively., ${ }^{5,29}$ 
<smiles></smiles>

23

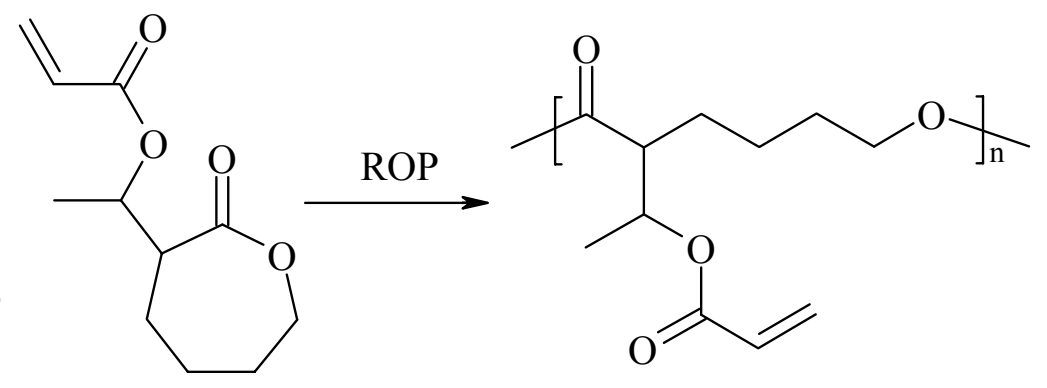

\section{Scheme 7}

However, these monomers 22 and $\mathbf{2 3}$ are poorly stable and they spontaneously form gels whenever they are not stored at low temperature and added with a radical scavenger. In this work, 5-azidooxepan-2-one 10 was converted into [1-(7-oxooxepan-4-yl)-1H-1,2,3-triazol-4yl]methyl acrylate 24 and 2-[1-(7-oxooxepan-4-yl)-1H-1,2,3-triazol-4-yl]ethyl acrylate 25 by reaction with prop-2-yn-1-yl acrylate 26 and but-3-yn-1-yl acrylate 27, respectively (Scheme 4). These new acrylates substituted lactones prepared by "click" chemistry are stable at room temperature at least for several weeks, even in the absence of any radical scavenger.

Finally, hydrophilic PEO chains were attached to the key lactone $\mathbf{1 0}$ in order to prepare macromonomers, that can be copolymerized with oxepane-2-one with formation of amphiphilic PCL-graft-PEO graft copolymers. These copolymers can thus form micelles in water an be used as surfactants for the preparation of drug loaded nanoparticles. ${ }^{30,31}$ Previously, a PEO-substituted lactone $\mathbf{2 8}$ was synthesized by Baeyer-Villiger oxidation of the parent cyclohexanone 29 (scheme 8). ${ }^{32}$ 


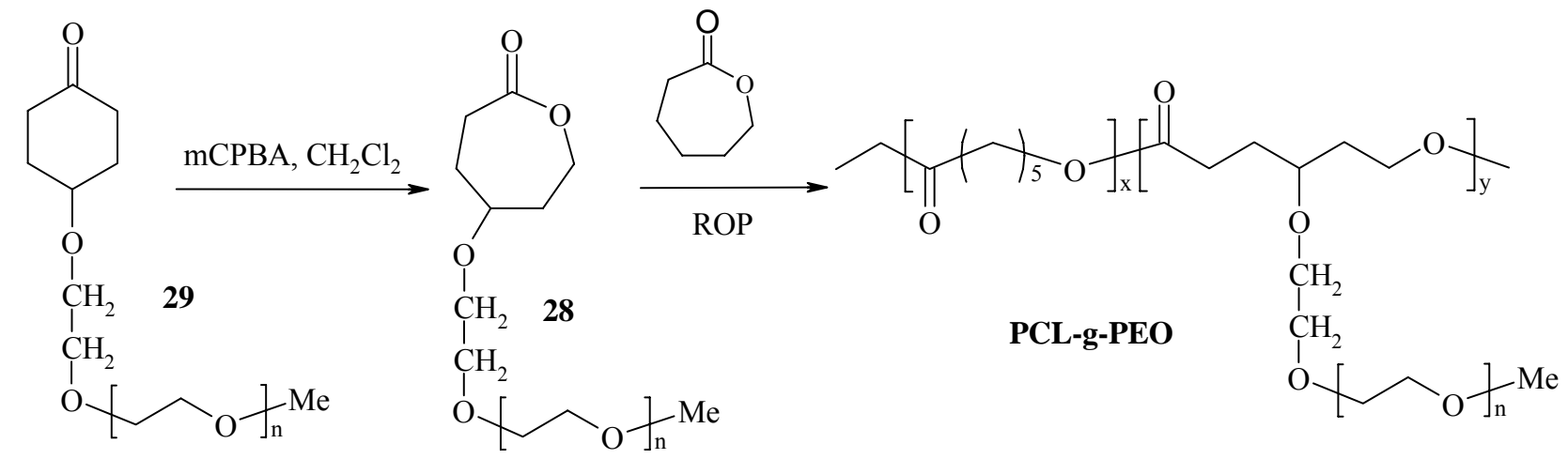

\section{Scheme 8}

In this work, the "click" cycloaddition of PEO 30 capped by an alkyne at one chain-end onto 5-azidooxepan-2-one 10 turned out to be a very efficient method for the synthesis of the macromonomer 31 (Scheme 4). The molecular weight was determined from the integrals of the ${ }^{1} \mathrm{H}$ NMR singlet at $3.6 \mathrm{ppm}$ for the repeating units and at $4.8 \mathrm{ppm}$ for the chain-end. It was in close agreement with the $M_{n}$ value of the original PEO $30\left(M_{n}=770 \mathrm{~g} / \mathrm{mol}\right)$, which unambiguously proved that the conversion of the "click" reaction was higher than $90 \%$.

It is very well-known that contamination of lactones by traces of protic species, such as alcohols and acids, is very detrimental to the control of the ring-opening polymerisation initiated by tin (IV) or aluminum alkoxides. It must be noted that the substituted oxepan-2-ones synthesized by "click" chemistry, were merely purified by recrystallization and proved to be pure enough for their polymerization to be controlled, even though copper catalytic residues were not completely eliminated. The yield of the "click" reactions carried out in this work was very high (see experimental part). A detailed discussion of the polymerization of the lactones synthesized by "click" reaction was however beyond the scope of this paper and will be reported in forthcoming papers.

One drawback of Huisgen's [3+2] cycloadditions remains the handling of azides, which are known to easily explode. ${ }^{33}$ This limitation was tackled by implementing a "one-step" strategy where the intermediate azide was not isolated. First, sodium azide and 5-bromooxepan-2-one 6 were reacted in DMF at $45^{\circ} \mathrm{C}$ for $48 \mathrm{~h}$. Then, prop-2-yn-1-yl acrylate 26, $\mathrm{CuI}$ and triethylamine were immediately added to the reaction medium. $2 \mathrm{~h}$ later, the reaction was complete and [1-(7oxooxepan-4-yl)-1H-1,2,3-triazol-4-yl]methyl acrylate 24 was formed, recrystallized and collected within a quantitative yield (see experimental part).

As a conclusion, the "click" cycloaddition is a very efficient technique for attaching a variety of functional groups onto oxepane-2-one in a quantitative way, under conditions mild enough for the lactone to be stable. An additional advantage has to be found in the easy purification of these monomers by recrystallization. Because of the high tolerance of this "click" reaction, no cumbersome protection/deprotection reactions were required for substituting the lactone ring by a hydroxyl group. Future work will be dedicated to supported catalysis with the purpose of 
separating easily the catalyst from the lactone and having it recycled. Finally, this work paves the way to the sequential polymerization of $\varepsilon$-caprolactones functionalized by "click" chemistry, so leading to diblock copolymers where each block has a specific functionality/reactivity, which was not possible when the azide groups were attached to the polyester chains rather than to the monomer $^{25}$.

\section{Experimental Section}

General Procedures. ${ }^{1} \mathrm{H}$ NMR spectra were recorded at $400 \mathrm{MHz}$ in the FT mode with a Brucker AN 400 apparatus at $25^{\circ} \mathrm{C}$. FT-IR spectra were recorded with a Perkin Elmer One apparatus. Differential scanning calorimetry (DSC) was carried out with a TA DSC Q100 thermal analyzer calibrated with indium. Melting temperatures were measured after a first cooling $\left(-80^{\circ} \mathrm{C}\right)$ and heating $\left(180^{\circ} \mathrm{C}\right)$ cycle.

\section{Synthesis and characterization}

Toluene (Chem-lab), tetrahydrofuran (THF, Chem-lab), diethyl ether (Chem-lab), N,Ndimethylformamide (DMF, Aldrich), dichloromethane $\left(\mathrm{CH}_{2} \mathrm{Cl}_{2}\right.$, Chem-Lab) sodium azide (Aldrich), triethylamine (Aldrich), $\mathrm{Cu}(\mathrm{I})$ iodide (Aldrich), 1-bromooctane (Aldrich), N,Ndimethylprop-2-yn-1-amine (Aldrich), acryloyl chloride (Aldrich), but-3-yn-1-ol (4, Aldrich), prop-2-yn-1-yl benzoate (11, Aldrich), prop-2-yn-1-ol (16, Aldrich) and prop-2-yn-1-yl acrylate (26, Aldrich) were used as received. The synthesis of 3-chlorooxepan-2-one (1) ${ }^{27}$, 5bromooxepan-2-one $(\mathbf{6})^{20}, 2$-bromo-2-methyl propionate $(\mathbf{2 0})^{34}$ and alkyn end-capped PEO ${ }^{26}$ (30) were reported elsewhere.

3-Azidooxepan-2-one (3). $10 \mathrm{~g}(67 \mathrm{mmol})$ of 3-chlorooxepan-2-one 1 were transferred into a glass reactor containing $50 \mathrm{ml}$ of DMF. $22 \mathrm{~g}(335 \mathrm{mmol})$ of $\mathrm{NaN}_{3}$ were then added, and the solution was stirred at $45^{\circ} \mathrm{C}$ for $72 \mathrm{~h}$. The solution was then filtrated and transferred in a separator funnel before to be diluted with $100 \mathrm{ml}$ of $\mathrm{CH}_{2} \mathrm{Cl}_{2}$. The organic layer was washed with $50 \mathrm{ml}$ of a saturated solution of $\mathrm{NaHCO}_{3}, 50 \mathrm{ml}$ of brine and $50 \mathrm{ml}$ of water, respectively. After drying over anhydrous $\mathrm{MgSO}_{4}$ and filtration, the solvents were eliminated in vacuo. $7.3 \mathrm{~g} \mathrm{(47}$ mmol) of 3-azidooxepan-2-one 3 were collected (Yield $=69 \%$ ).

Crude oil. ${ }^{1} \mathrm{H}$ NMR (250 MHz, $\left.\mathrm{CDCl}_{3}\right): \delta$ 1.6-2.1 (6H, m, $\left.\underline{\mathrm{CH}}_{2}-\underline{\mathrm{C}}_{2}-\mathrm{C}_{2}-\mathrm{CHN}_{3}\right), 4.1(2 \mathrm{H}, \mathrm{m}$, $\mathrm{C}(\mathrm{H}) \underline{\mathrm{H}}-\mathrm{O}-\mathrm{CO}$ and $\left.\mathrm{CH}-\mathrm{N}_{3}\right), 4.4(1 \mathrm{H}, \mathrm{m}, \mathrm{C}(\mathrm{H}) \underline{\mathrm{H}}-\mathrm{O}-\mathrm{CO}) ;{ }^{13} \mathrm{C} \mathrm{NMR}\left(400 \mathrm{MHz}, \mathrm{CDCl}_{3}\right): \delta .26 .8$

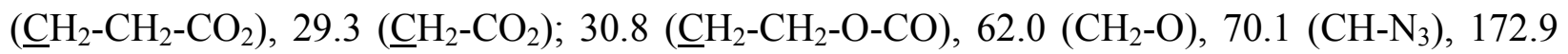
$(\mathrm{C}=\mathrm{O}) ; \operatorname{IR} \delta\left(\mathrm{cm}^{-1}\right): 2108\left(\mathrm{~N}_{3}\right), 1740(\mathrm{C}=\mathrm{O})$.

5-Azidooxepan-2-one (10). $10 \mathrm{~g}(52 \mathrm{mmol})$ of 5-bromooxepan-2-one 6 were transferred into a glass reactor containing $50 \mathrm{ml}$ of DMF. $4 \mathrm{~g}(63 \mathrm{mmol})$ of $\mathrm{NaN}_{3}$ were then added and the solution was stirred at $45^{\circ} \mathrm{C}$ for $48 \mathrm{~h}$. DMF was removed in vacuo, and the solid was dissolved in $\mathrm{CH}_{2} \mathrm{Cl}_{2}$. The solution was then sonicated for $5 \mathrm{~min}$. before being transferred in a separator funnel. The organic layer was washed with $50 \mathrm{ml}$ of a saturated solution of $\mathrm{NaHCO}_{3}, 50 \mathrm{ml}$ of brine and 50 
$\mathrm{ml}$ of water, respectively. After drying over anhydrous $\mathrm{MgSO}_{4}$ and filtration, $\mathrm{CH}_{2} \mathrm{Cl}_{2}$ was eliminated in vacuo. $7.6 \mathrm{~g}$ (49 mmol) of 5-azidooxepan-2-one 10 were collected (Yield = $94 \%$ ). Crude oil; ${ }^{1} \mathrm{H}$ NMR $\left(250 \mathrm{MHz}, \mathrm{CDCl}_{3}\right) \delta 1.8-2.0\left(4 \mathrm{H}, \mathrm{m}, \mathrm{C}_{2}-\mathrm{CHN}_{3}-\mathrm{C}_{2}\right), 2.5(1 \mathrm{H}, \mathrm{m}, \mathrm{C}(\mathrm{H}) \underline{\mathrm{H}}-$ $\left.\mathrm{CO}_{2}\right), 2.8\left(1 \mathrm{H}, \mathrm{m}, \mathrm{C}(\mathrm{H}) \underline{\mathrm{H}}-\mathrm{CO}_{2}\right), 3.8(1 \mathrm{H}, \mathrm{m}, \mathrm{CHN}), 4.1(1 \mathrm{H}, \mathrm{m}, \mathrm{C}(\mathrm{H}) \underline{\mathrm{H}}-\mathrm{O}-\mathrm{CO}), 4.4(1 \mathrm{H}, \mathrm{m}$,

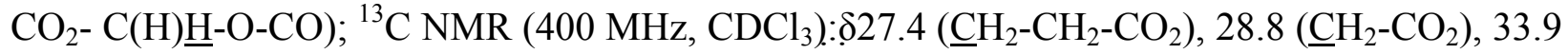
$\left(\underline{\mathrm{CH}}_{2}-\mathrm{CH}_{2}-\mathrm{O}-\mathrm{CO}\right), 58.9\left(\mathrm{CH}-\mathrm{N}_{3}\right), 63.6\left(\mathrm{CH}_{2}-\mathrm{O}\right), 174.7(\mathrm{C}=\mathrm{O}) ; \mathrm{RI} \delta\left(\mathrm{cm}^{-1}\right) 2100\left(\mathrm{~N}_{3}\right), 1730$ $(\mathrm{C}=\mathrm{O})$.

[1-(7-oxooxepan-4-yl)-1H-1,2,3-triazol-4-yl]methyl benzoate (12). $500 \mathrm{mg}$ (3.2 mmol) of 5azidooxepan-2-one 10 were transferred into a glass reactor containing $2 \mathrm{ml}$ of a mixture $1 / 1$ of THF and DMF. $525 \mathrm{mg}(3.5 \mathrm{mmol})$ of prop-2-yn-1-yl benzoate 11, $67 \mathrm{mg}(0.35 \mathrm{mmol})$ of CuI and $35 \mathrm{mg}(0.35 \mathrm{mmol})$ of $\mathrm{NEt}_{3}$ were added into the reactor and the solution was stirred at $35^{\circ} \mathrm{C}$. After $2 \mathrm{~h}$, the solution was concentrated in vacuo and transferred into $50 \mathrm{ml}$ of diethylether and placed at $-20^{\circ} \mathrm{C}$ overnight. The crystals were filtrated and dried in vacuo (Yield $=93 \%$ ).

Brown crystals (recrystalized from diethylether); mp: $153{ }^{\circ} \mathrm{C} ;{ }^{1} \mathrm{H}$ NMR (250 MHz, DMSO) 2.03.0 (6H, massif, $\underline{\mathrm{CH}}_{2}-\mathrm{CH}$ (triazole)- $\left.\underline{\mathrm{C}}_{2}-\underline{\mathrm{C}}_{2}-\mathrm{CO}_{2}\right), 4.4\left(1 \mathrm{H}, \mathrm{m}, \mathrm{CH}_{2}-\mathrm{C}(\mathrm{H}) \underline{\mathrm{H}}-\mathrm{O}-\mathrm{CO}\right), 4.5(1 \mathrm{H}, \mathrm{m}$, $\left.\mathrm{CH}_{2}-\mathrm{C}(\mathrm{H}) \underline{\mathrm{H}}-\mathrm{O}-\mathrm{CO}\right), 4.9$ (1H, m, C -triazole), 5.4 (2H, s, $\left.\mathrm{CH}_{2}-\mathrm{O}-\mathrm{CO}-\mathrm{Ph}\right), 7.5,7.6$ and 8.0 (5H, 3 $\mathrm{m}$, aromatic protons), $8.4\left(1 \mathrm{H}, \mathrm{s}\right.$, triazole); ${ }^{13} \mathrm{C} \mathrm{NMR}(400 \mathrm{MHz}, \mathrm{DMSO}): \delta 28.3\left(\underline{\mathrm{CH}_{2}-\mathrm{CH}_{2}-}\right.$ $\left.\mathrm{CO}_{2}\right), 29.8\left(\underline{\mathrm{CH}}_{2}-\mathrm{CO}_{2}\right), 35.0\left(\underline{\mathrm{CH}}_{2}-\mathrm{CH}_{2}-\mathrm{O}-\mathrm{CO}\right), 57.8$ and 59.1 (2 $\left.\underline{\mathrm{CH}}_{2}-\mathrm{OC}(\mathrm{O})\right), 64.5(\underline{\mathrm{CH}}-$ triazole), $122.9\left[\mathrm{CH}\right.$ (triazole)],128.5 $\left(\mathrm{C}\right.$ aromatic $\left.\left(\mathrm{C}_{6} \mathrm{H}_{5}\right)\right), 129.0\left(\mathrm{C}\right.$ aromatic $\left.\left(\mathrm{C}_{6} \mathrm{H}_{5}\right)\right), 133.2(\mathrm{C}$ aromatic $\left.\left(\mathrm{C}_{6} \mathrm{H}_{5}\right)\right), 143.7$ [quaternary $\mathrm{C}$ (triazole)], $165.1(\mathrm{Ph}-\mathrm{C}=\mathrm{O}), 174.1(\mathrm{C}=\mathrm{O}) ; \mathrm{IR} \delta\left(\mathrm{cm}^{-1}\right)$ : $1719(\underline{\mathrm{C}}=\mathrm{O}), 1667(\mathrm{C}=\mathrm{C})$.

$\boldsymbol{N}, \boldsymbol{N}$-Dimethyl- $\boldsymbol{N}$-prop-2-yn-1-yloctan-1-ammonium bromide (13). $7 \mathrm{~g}$ (36.2 mmol) of 1 bromooctane were added in a glass reactor containing $20 \mathrm{ml}$ of THF, followed by $3.6 \mathrm{~g}$ (43.4 mmol) of $N, N$-dimethylprop-2-yn-1-amine. After 2 days at $50^{\circ} \mathrm{C}$, the solvent was evaporated in vacuo. The ammonium salt was dissolved in THF and purified by two repeating precipitation in cyclohexane. The final yield was $81 \% . \mathrm{NMR}{ }^{1} \mathrm{H}\left(250 \mathrm{MHz}, \mathrm{CDCl}_{3}\right): \delta 4.8\left(2 \mathrm{H}, \mathrm{m}, \mathrm{CH}_{2} \mathrm{~N}^{+}\right), 3.6$ $\left(2 \mathrm{H}, \mathrm{m}, \mathrm{N}^{+} \mathrm{CH}_{2}\right), 3.4\left(6 \mathrm{H}, \mathrm{m}, 2 \mathrm{~N}^{+} \mathrm{CH}_{3}\right), 2.9(1 \mathrm{H}, \mathrm{m}, \mathrm{C} \equiv \mathrm{CH}), 1.7-1.2\left(12 \mathrm{H}, \mathrm{m}, 6 \mathrm{CH}_{2}\right), 0.8 \mathrm{ppm}$ $\left(3 \mathrm{H}, \mathrm{m}, \mathrm{CH}_{3}\right) ; \mathrm{NMR}{ }^{13} \mathrm{C}\left(250 \mathrm{MHz}, \mathrm{CDCl}_{3}\right): \delta=85.6(\mathrm{HC} \equiv \underline{\mathrm{C}}), 82.3\left(\mathrm{HC} \equiv \mathrm{C}-\underline{\mathrm{CH}}_{2} \mathrm{~N}^{+}\right), 72.6$

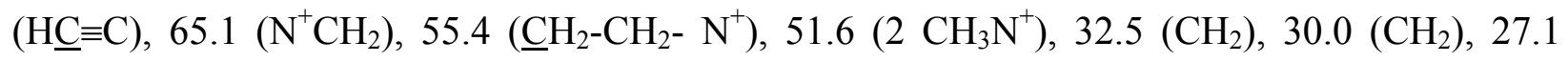
$\left(\mathrm{CH}_{2}\right), 23.8\left(\mathrm{CH}_{2}\right), 23.5\left(\mathrm{CH}_{2}\right), 14 \mathrm{ppm}\left(\mathrm{CH}_{3}\right)$.

\section{$N, N$-Dimethyl-N-\{[1-(7-oxooxepan-4-yl)-1H-1,2,3-triazol-4-yl]methyloctan-1-ammonium}

bromide (14). $500 \mathrm{mg}(3.2 \mathrm{mmol})$ of 5-azidooxepan-2-one 10 were transferred into a glass reactor containing $2 \mathrm{ml}$ of a mixture $1 / 1$ of THF and DMF. $890 \mathrm{mg}(3.5 \mathrm{mmol})$ of $N, N$-dimethyl$N$-prop-2-yn-1-yloctan-1-ammonium bromide $13,67 \mathrm{mg}(0.35 \mathrm{mmol})$ of $\mathrm{CuI}$ and $35 \mathrm{mg}(0.35$ mmol) of $\mathrm{NEt}_{3}$ were then added, and the solution was stirred at $35^{\circ} \mathrm{C}$. After $2 \mathrm{~h}$, the solution was concentrated in vacuo and transferred into $50 \mathrm{ml}$ of diethylether and placed at $-20^{\circ} \mathrm{C}$ overnight. The crystals were filtrated and dried in vacuo (Yield $=89 \%$ ). Green crystals (recrystalized from diethylether); mp: $164^{\circ} \mathrm{C}$; ${ }^{1} \mathrm{H}$ NMR $(250 \mathrm{MHz}, \mathrm{DMSO}) \delta 0.8\left(3 \mathrm{H}, \mathrm{t}, \mathrm{CH}_{3}\right.$ of the octyl chain), 1.2 $\left(10 \mathrm{H}, \mathrm{m}, 5 \mathrm{CH}_{2}\right.$ of the octyl chain), $1.7\left(2 \mathrm{H}, \mathrm{m}, \mathrm{CH}_{2}-\mathrm{CH}_{2}-\mathrm{N}(+)\right), 2.0-2.4\left(4 \mathrm{H}, \mathrm{m}, \mathrm{CH}_{2}\right), 2.5(1 \mathrm{H}$, m, $\left.\mathrm{C}(\mathrm{H}) \underline{\mathrm{H}}-\mathrm{CO}_{2}\right), 2.9\left(1 \mathrm{H}, \mathrm{m}, \mathrm{C}(\mathrm{H}) \underline{\mathrm{H}}-\mathrm{CO}_{2}\right), 3.0\left(6 \mathrm{H}, \mathrm{s},\left(\mathrm{CH}_{3}\right)_{2}-\mathrm{N}(+)\right), 3.1\left(2 \mathrm{H}, \mathrm{m}, \mathrm{CH}_{2}-\mathrm{N}(+)\right), 4.3$ 
$(1 \mathrm{H}, \mathrm{m}, \mathrm{C}(\mathrm{H}) \underline{\mathrm{H}}-\mathrm{O}-\mathrm{CO}), 4.5(1 \mathrm{H}, \mathrm{m}, \mathrm{C}(\mathrm{H}) \underline{\mathrm{H}}-\mathrm{O}-\mathrm{CO}), 4.6\left(2 \mathrm{H}, \mathrm{s}\right.$, triazole- $\left.\underline{\mathrm{H}}_{2}-\mathrm{N}(+)\right), 4.9(1 \mathrm{H}, \mathrm{m}$, Cㅡ-H-triazole), $8.5\left(1 \mathrm{H}, \mathrm{s}\right.$, triazole); ${ }^{13} \mathrm{C} \mathrm{NMR}\left(400 \mathrm{MHz}, \mathrm{CDCl}_{3}\right) \delta 14.4\left(\mathrm{CH}_{3} \mathrm{CH}_{2}\right), 22.2\left(\mathrm{CH}_{2}\right)$, $22.5\left(\mathrm{CH}_{2}\right), 26.3\left(\mathrm{CH}_{2}\right), 28.9\left(\mathrm{CH}_{2}\right), 30.5\left(\mathrm{CH}_{2}\right), 31.6\left(\mathrm{CH}_{2} \mathrm{CO}_{2}\right), 35,6\left(\underline{C H}_{2}-\mathrm{CH}_{2} \mathrm{O}-\mathrm{CO}\right), 50.0$ $\left(\left(\mathrm{CH}_{3}\right)_{2}-\mathrm{N}(+), 57.6\right.$ (triazole- $\underline{\mathrm{H}}_{2}-\mathrm{N}(+), 59.9\left(\underline{\mathrm{CH}}\right.$-triazole), $63.3\left(\mathrm{CH}_{2}-\underline{\mathrm{CH}}_{2}-\mathrm{N}(+)\right), 65.2\left(\mathrm{CH}_{2}-\mathrm{O}\right)$, $127.0\left[\mathrm{CH}\right.$ (triazole)], 135.6 [quaternary $\mathrm{C}$ (triazole)], $174.9(\mathrm{C}=\mathrm{O})$; IR $\delta\left(\mathrm{cm}^{-1}\right): 1732(\mathrm{C}=\mathrm{O})$, 1634 (triazole)

5-[4-(Hydroxymethyl)-1H-1,2,3-triazol-1-yl]oxepan-2-one (17). $500 \mathrm{mg}$ (3.2 mmol) of 5azidooxepan-2-one 10 were transferred into a glass reactor containing $2 \mathrm{ml}$ of a mixture 1/1 of THF and DMF. $196 \mathrm{mg}$ (3.5 mmol) of prop-2-yn-1-ol 16, $67 \mathrm{mg}(0.35 \mathrm{mmol})$ of CuI and $35 \mathrm{mg}$ $(0.35 \mathrm{mmol})$ of $\mathrm{NEt}_{3}$ were then added, and the solution was stirred at $35^{\circ} \mathrm{C}$. After $2 \mathrm{~h}$, the solution was concentrated in vacuo and transferred into $50 \mathrm{ml}$ of diethylether and placed at $-20^{\circ} \mathrm{C}$ overnight. The crystals were filtrated and dried in vacuo (Yield $=91 \%$ ). yellow crystals (recrystalized from diethylether); mp: $181{ }^{\circ} \mathrm{C} ;{ }^{1} \mathrm{H}$ NMR $(250 \mathrm{MHz}, \mathrm{DMSO}) \delta 2.0-2.4(4 \mathrm{H}, \mathrm{m}$, $\left.\mathrm{CH}_{2}\right), 2.5\left(1 \mathrm{H}, \mathrm{m}, \mathrm{C}(\mathrm{H}) \underline{\mathrm{H}}-\mathrm{CO}_{2}\right), 2.9\left(1 \mathrm{H}, \mathrm{m}, \mathrm{C}(\mathrm{H}) \underline{\mathrm{H}}-\mathrm{CO}_{2}\right), 4.3-4.5\left(4 \mathrm{H}, \mathrm{m}, \mathrm{CH}_{2} \mathrm{OH}\right.$ and $\mathrm{CH}_{2^{-}}$ OCO), 4.9 (1H, m, CH-triazole), $5.2(1 \mathrm{H}, \mathrm{m}, \mathrm{OH}), 8.1\left(1 \mathrm{H}, \mathrm{s}\right.$, triazole); ${ }^{13} \mathrm{C} \mathrm{NMR} \mathrm{(400} \mathrm{MHz,}$ $\left.\mathrm{CDCl}_{3}\right) \delta 29.1\left(\underline{\mathrm{CH}}_{2}-\mathrm{CH}_{2} \mathrm{CO}_{2}\right), 30.6\left(\underline{\mathrm{CH}}_{2} \mathrm{CO}_{2}\right), 35.7\left(\underline{\mathrm{CH}}_{2}-\mathrm{CH}_{2} \mathrm{O}-\mathrm{CO}\right), 55.5\left(\underline{\mathrm{C}} \mathrm{H}_{2}-\mathrm{OH}\right), 59.6$ (ㄷH-triazole), $65.3\left(\underline{\mathrm{CH}}_{2}-\mathrm{OCO}\right), 121.6[\mathrm{CH}$ (triazole)], 148.6 [quaternary $\mathrm{C}$ (triazole)], 175.0 $(\mathrm{C}=\mathrm{O})$; IR $\delta\left(\mathrm{cm}^{-1}\right): 3233(\mathrm{O}-\mathrm{H}), 1727(\mathrm{C}=\mathrm{O}), 1661(\mathrm{C}=\mathrm{C})$.

5-[4-(Hydroxyethyl)-1H-1,2,3-triazol-1-yl]oxepan-2-one (18). $500 \mathrm{mg}$ (3.2 mmol) of 5azidooxepan-2-one 10 were transferred into a glass reactor containing $2 \mathrm{ml}$ of a mixture $1 / 1$ of THF and DMF. $245 \mathrm{mg}(3.5 \mathrm{mmol})$ of but-3-yn-1-ol 4, $67 \mathrm{mg}(0.35 \mathrm{mmol})$ of CuI and $35 \mathrm{mg}$ $(0.35 \mathrm{mmol})$ of $\mathrm{NEt}_{3}$ were then added, and the solution was stirred at $35^{\circ} \mathrm{C}$. After $2 \mathrm{~h}$, the solution was concentrated in vacuo and transferred into $50 \mathrm{ml}$ of diethylether and placed at $-20^{\circ} \mathrm{C}$ overnight. The crystals were filtrated and dried in vacuo (Yield $=93 \%$ ); yellow crystals (recrystalized from diethylether); mp: $115^{\circ} \mathrm{C} ;{ }^{1} \mathrm{H} \mathrm{NMR}\left(250 \mathrm{MHz}, \mathrm{CDCl}_{3}\right) \delta 2.2-2.7(4 \mathrm{H}$, massif, $2 \mathrm{CH}_{2}$ and $\left.\mathrm{C}(\mathrm{H}) \underline{\mathrm{H}}-\mathrm{CO}_{2}\right), 2.9\left(3 \mathrm{H}, \mathrm{m}, \mathrm{C}(\mathrm{H}) \underline{\mathrm{H}}-\mathrm{CO}_{2}\right.$ and $\left.\mathrm{C}_{2}-\mathrm{CH}_{2} \mathrm{OH}\right), 3.9\left(2 \mathrm{H}, \mathrm{t}, \mathrm{CH}_{2}-\mathrm{OH}\right), 4.3$ $(1 \mathrm{H}, \mathrm{m}, \mathrm{C}(\mathrm{H}) \underline{\mathrm{H}}-\mathrm{O}), 4.5(1 \mathrm{H}, \mathrm{m}, \mathrm{C}(\mathrm{H}) \underline{\mathrm{H}}-\mathrm{O}), 4.8(1 \mathrm{H}, \mathrm{m}, \mathrm{CH}$-triazole $), 7.4(1 \mathrm{H}, \mathrm{s}$, triazole $) ;{ }^{13} \mathrm{C}$ NMR $\left(400 \mathrm{MHz}, \mathrm{CDCl}_{3}\right) \delta 29.2\left(\mathrm{CH}_{2} \mathrm{CH}_{2}-\mathrm{CO}_{2}\right), 29.7$ and 30.6 (triazole- $\mathrm{CH}_{2}-\mathrm{CH}_{2}$ and $\underline{\mathrm{CH}_{2}-}$

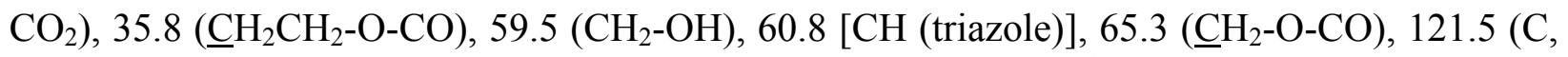
triazole), 145.3 [quaternary $\mathrm{C}$ (triazole)], $175.0(\mathrm{C}=\mathrm{O})$; IR $\delta\left(\mathrm{cm}^{-1}\right): 3448(\mathrm{O}-\mathrm{H}), 1727(\mathrm{C}=\mathrm{O})$, $1665(\mathrm{C}=\mathrm{C})$.

[1-(7-Oxooxepan-4-yl)-1H-1,2,3-triazol-4-yl]methyl 2-bromo-2-methylpropanoate (21). 500 $\mathrm{mg}$ (3.2 mmol) of 5-azidooxepan-2-one 10 were transferred into a glass reactor containing $2 \mathrm{ml}$ of a mixture 1/1 of THF and DMF. $720 \mathrm{mg}(3.5 \mathrm{mmol})$ of prop-2-yn-1-yl 2-bromo-2methylpropanoate $20,67 \mathrm{mg}(0.35 \mathrm{mmol})$ of $\mathrm{CuI}$ and $35 \mathrm{mg}(0.35 \mathrm{mmol})$ of $\mathrm{NEt}_{3}$ were then added, and the solution was stirred at $35^{\circ} \mathrm{C}$. After $2 \mathrm{~h}$, the solution was concentrated in vacuo and transferred into $50 \mathrm{ml}$ of diethylether and placed at $-20^{\circ} \mathrm{C}$ overnight. The crystals were filtrated and dried in vacuo (Yield $=97 \%$ ). Green crystals (recrystalized from diethylether) 
mp: $120^{\circ} \mathrm{C} ;{ }^{1} \mathrm{H}$ NMR $\left(250 \mathrm{MHz}, \mathrm{CDCl}_{3}\right) \delta 1.9\left(6 \mathrm{H}, \mathrm{s}, 2 \mathrm{CH}_{3}\right), 2.2-2.7\left(5 \mathrm{H}\right.$, massif, $2 \mathrm{CH}_{2}$ and $\left.\mathrm{C}(\mathrm{H}) \underline{\mathrm{H}}-\mathrm{CO}_{2}\right), 2.9\left(1 \mathrm{H}, \mathrm{m}, \mathrm{C}(\mathrm{H}) \underline{\mathrm{H}}-\mathrm{CO}_{2}\right), 4.3\left(1 \mathrm{H}, \mathrm{m}, \mathrm{C}(\mathrm{H}) \underline{\mathrm{H}}-\mathrm{OCO}-\mathrm{CH}_{2}\right), 4.5(1 \mathrm{H}, \mathrm{m}, \mathrm{HC}(\mathrm{H}) \underline{\mathrm{H}}-$ OCO- $\left.\mathrm{CH}_{2}\right), 4.8(1 \mathrm{H}, \mathrm{m}, \mathrm{CH}$-triazole $), 5.3\left(2 \mathrm{H}, \mathrm{s}, \mathrm{C}_{2}-\mathrm{O}-\mathrm{C}(\mathrm{O})-\mathrm{C}\left(\mathrm{CH}_{3}\right)_{2} \mathrm{Br}\right) 7.7(1 \mathrm{H}, \mathrm{s}$, triazole $)$

${ }^{13} \mathrm{C}$ NMR $\left(400 \mathrm{MHz}, \mathrm{CDCl}_{3}\right) \delta 29.1\left(\mathrm{CH}_{2}-\mathrm{CH}_{2}-\mathrm{CO}_{2}\right), 30.5\left(\mathrm{CH}_{2}-\mathrm{CH}_{2}-\mathrm{CO}_{2}\right), 30.7\left[\left(\mathrm{CH}_{3}\right)_{2} \mathrm{CBr}-\right.$ $\left.\mathrm{CO}_{2}-\right], 35.7\left(\underline{\mathrm{CH}}_{2}-\mathrm{CH}_{2} \mathrm{O}-\mathrm{CO}\right), 57.4\left[\left(\mathrm{CH}_{3}\right)_{2} \underline{\mathrm{CBr}}-\mathrm{CO}_{2}-\right], 59.4\left(\underline{\mathrm{CH}}_{2}-\mathrm{O}-\mathrm{C}(\mathrm{O})-\mathrm{C}\left(\mathrm{CH}_{3}\right)_{2} \mathrm{Br}\right), 59,9$ (ㅡㅐ-triazole), $65.2\left(\underline{\mathrm{CH}}_{2}-\mathrm{OCO}-\mathrm{CH}_{2}\right), 123,6$ [CH (triazole)], 141.8 [quaternary $\mathrm{C}$ (triazole)], $170.9(\mathrm{C}=\mathrm{O}), 174.9(\mathrm{C}=\mathrm{O})$; IR $\delta\left(\mathrm{cm}^{-1}\right)$ : $1735(\mathrm{C}=\mathrm{O}), 1671$ (triazole).

[1-(7-Oxooxepan-4-yl)-1H-1,2,3-triazol-4-yl]methyl acrylate (24)._500 mg (3.2 mmol) of 5azidooxepan-2-one 10 were transferred into a glass reactor containing $2 \mathrm{ml}$ of THF. $385 \mathrm{mg}$ (3.5 mmol) of prop-2-yn-1-yl acrylate $26,67 \mathrm{mg}(0.35 \mathrm{mmol})$ of $\mathrm{CuI}$ and $35 \mathrm{mg}(0.35 \mathrm{mmol}) \mathrm{of} \mathrm{NEt}_{3}$ were added into the reactor, and the solution was stirred at $35^{\circ} \mathrm{C}$. After $2 \mathrm{~h}$, the solution was placed at $-20^{\circ} \mathrm{C}$ overnight. The crystals were then filtrated and dried in vacuo (Yield $=96 \%$ ).

Green crystals (recrystalized from THF), mp: $100{ }^{\circ} \mathrm{C} ;{ }^{1} \mathrm{H}$ NMR $\left(250 \mathrm{MHz}, \mathrm{CDCl}_{3}\right) \delta \delta 2.0-2.6$ (4H,massif, $\underline{\mathrm{C}}_{2}-\mathrm{CH}\left(\right.$ triazole) $\left.-\mathrm{CH}_{2}\right), 3.1(2 \mathrm{H}, \mathrm{m}), 2.75\left(1 \mathrm{H}, \mathrm{m}, \mathrm{CH}_{2}-\mathrm{C}(\mathrm{H}) \underline{\mathrm{H}}-\mathrm{CO}_{2}\right), 3.0(1 \mathrm{H}, \mathrm{m}$, $\left.\mathrm{CH}_{2}-\mathrm{C}(\mathrm{H}) \underline{\mathrm{H}}-\mathrm{CO}_{2}\right), 4.3\left(1 \mathrm{H}, \mathrm{m}, \mathrm{C}(\mathrm{H}) \underline{\mathrm{H}}-\mathrm{O}-\mathrm{CO}-\mathrm{CH}_{2}\right), 4.6\left(1 \mathrm{H}, \mathrm{m}, \mathrm{C}(\mathrm{H}) \underline{\mathrm{H}}-\mathrm{O}-\mathrm{CO}-\mathrm{CH}_{2}\right), 4.8(1 \mathrm{H}, \mathrm{m}$, CH-triazole) $5.3\left(2 \mathrm{H}, \mathrm{m}, \underline{\mathrm{C}}_{2} \mathrm{O}-\mathrm{CO}-\mathrm{CH}=\mathrm{CH}_{2}\right), 5.8\left(1 \mathrm{H}, \mathrm{d}, \mathrm{J}=10 \mathrm{~Hz}, \mathrm{C}(\mathrm{H}) \underline{\mathrm{H}}_{\mathrm{cis}}=\mathrm{CH}-\mathrm{CO}_{2}\right), 6.1$ $\left(1 \mathrm{H}, \mathrm{dd}, \mathrm{J}=10\right.$ and $\left.17 \mathrm{~Hz}, \mathrm{CH}_{2}=\mathrm{C} \underline{\mathrm{H}}-\mathrm{CO}_{2}\right), 6.5\left(1 \mathrm{H}, \mathrm{d}, \mathrm{J}=17 \mathrm{~Hz}, \mathrm{C}(\mathrm{H}) \underline{\mathrm{H}}_{\text {trans }}=\mathrm{CH}-\mathrm{CO}_{2}\right), 7.8(1 \mathrm{H}$,

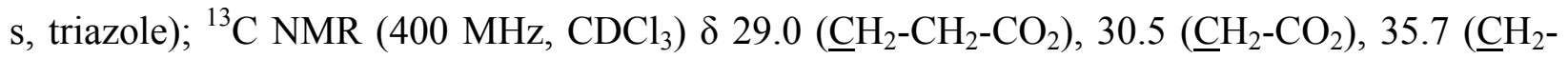
$\left.\mathrm{CH}_{2} \mathrm{O}\right), 57.8\left(\underline{\mathrm{CH}}_{2} \mathrm{O}-\mathrm{CO}-\mathrm{CH}=\mathrm{CH}_{2}\right), 59.9$ ( $\underline{\mathrm{CH}}$-triazole), $65.2\left(\underline{\mathrm{CH}}_{2} \mathrm{O}-\mathrm{CO}-\mathrm{CH}_{2}\right), 123.7[\mathrm{CH}$ (triazole)], $128.3\left(\mathrm{CH}_{2}=\underline{\mathrm{CH}}-\mathrm{CO}_{2}\right), 132.6\left(\underline{\mathrm{CH}}_{2}=\mathrm{CH}-\mathrm{CO}_{2}\right), 142.4$ [quaternary $\mathrm{C}$ (triazole)], 165.6 $(\mathrm{C}=\mathrm{O}), 174.9(\mathrm{C}=\mathrm{O})$; IR $\delta\left(\mathrm{cm}^{-1}\right): 1729(\mathrm{C}=\mathrm{O}), 1629(\mathrm{C}=\mathrm{C})$.

2-[1-(7-Oxooxepan-4-yl)-1H-1,2,3-triazol-4-yl]ethyl acrylate (25). $500 \mathrm{mg}$ (3.2 mmol) of 5azidooxepan-2-one 10 were transferred into a glass reactor containing $2 \mathrm{ml}$ of a mixture 1/1 of THF and DMF. $434 \mathrm{mg}$ (3.5 mmol) of but-3-yn-1-yl acrylate 27, $67 \mathrm{mg}(0.35 \mathrm{mmol})$ of CuI and $35 \mathrm{mg}(0.35 \mathrm{mmol})$ of $\mathrm{NEt}_{3}$ were then added, and the solution was stirred at $35^{\circ} \mathrm{C}$. After $2 \mathrm{~h}$, the solution was concentrated in vacuo and transferred into $50 \mathrm{ml}$ of diethylether and placed at $-20^{\circ} \mathrm{C}$ overnight. The crystals were filtrated and dried in vacuo (Yield $=94 \%$ ). Colorless crystals (recrystalized from diethylether); mp: $95{ }^{\circ} \mathrm{C} ;{ }^{1} \mathrm{H}$ NMR $\left(250 \mathrm{MHz}, \mathrm{CDCl}_{3}\right) \delta$ 2.0-2.5 (4H, m, $\underline{\mathrm{C}}_{2}-\mathrm{CH}\left(\right.$ triazole)- $\left.\underline{\mathrm{H}}_{2}\right), 2.75-3.1\left(4 \mathrm{H}, \mathrm{m}, \mathrm{CH}_{2}-\underline{\mathrm{C}}_{2}-\mathrm{CO}_{2}\right.$ and $\mathrm{CH}_{2}$-triazole), 4.2-4.6 (4H, m, $\left.\mathrm{CH}_{2} \mathrm{O}-\mathrm{CO}\right), 4.8(1 \mathrm{H}, \mathrm{m}, \mathrm{C} \underline{\mathrm{H}}$-triazole $), 5.8\left(1 \mathrm{H}, \mathrm{d}, \mathrm{J}=10 \mathrm{~Hz}, \mathrm{C}(\mathrm{H}) \underline{\mathrm{H}}_{\mathrm{cis}}=\mathrm{CH}-\mathrm{CO}_{2}\right), 6.1$ (1H, dd, J $=10$ and $\left.17 \mathrm{~Hz}, \mathrm{CH}_{2}=\mathrm{C} \underline{\mathrm{H}}-\mathrm{CO}_{2}\right), 6.4\left(1 \mathrm{H}, \mathrm{d}, \mathrm{J}=17 \mathrm{~Hz}, \mathrm{C}(\mathrm{H}) \underline{\mathrm{H}}_{\text {trans }}=\mathrm{CH}-\mathrm{CO}_{2}\right), 8.0(1 \mathrm{H}$, s, triazole $)$

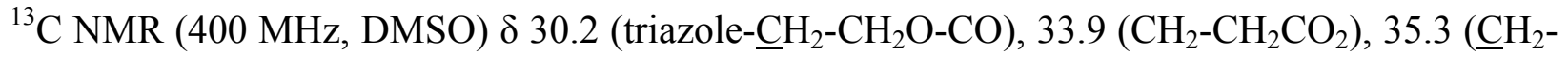
$\left.\mathrm{CO}_{2}\right), 40.5\left(\underline{\mathrm{CH}}_{2}-\mathrm{CH}_{2} \mathrm{O}-\mathrm{CO}\right), 64.5$ ( $\underline{\mathrm{CH}}$-triazole), $68.1\left(\underline{\mathrm{CH}}_{2} \mathrm{O}-\mathrm{CO}-\mathrm{CH}=\mathrm{CH}_{2}\right), 70.0\left(\underline{\mathrm{CH}}_{2} \mathrm{O}-\mathrm{CO}-\right.$ $\left.\mathrm{CH}_{2}\right), 126.6\left[\mathrm{CH}\right.$ (triazole)], $133.3\left(\mathrm{CH}_{2}=\mathrm{CH}-\mathrm{CO}_{2}\right), 136.7\left(\underline{\mathrm{CH}_{2}}=\mathrm{CH}-\mathrm{CO}_{2}\right), 148.7$ [quaternary $\mathrm{C}$ (triazole)], $170.6(\mathrm{C}=\mathrm{O}), 179.7(\mathrm{C}=\mathrm{O}) ; \mathbf{I R} \delta\left(\mathrm{cm}^{-1}\right)$ : $1730(\mathrm{C}=\mathrm{O}), 1641(\mathrm{C}=\mathrm{C})$.

But-3-yn-1-yl acrylate (27). $5 \mathrm{~g}(0.07 \mathrm{~mol})$ of but-3-yn-1-ol were transferred in a glass reactor containing $11 \mathrm{~g}(0.077 \mathrm{~mol})$ of triethylamine and $50 \mathrm{ml}$ of dried $\mathrm{CH}_{2} \mathrm{Cl}_{2}$. The solution was then cooled in ice bath before adding drop by drop $6.4 \mathrm{~g}(0.077 \mathrm{~mol})$ of acryloyl chloride. After complete addition, the solution was stirred overnight. After filtration, the organic layer was washed by $3 \times 50 \mathrm{ml}$ of $\mathrm{NaHCO}_{3}$ saturated solution and 3 X $50 \mathrm{ml}$ of water. After drying over 
$\mathrm{MgSO}_{4}$, the organic phase was filtered, and the solvent was removed under reduced pressure. The residue was distilled under reduced pressure, and $3 \mathrm{~g}$ of but-3-yn-1-yl acrylate (bp $=22-$ $25^{\circ} \mathrm{C}$ at $0.2 \mathrm{mmHg}$ ) was collected. (Yield $\left.=35 \%\right)$. NMR ${ }^{1} \mathrm{H}\left(250 \mathrm{MHz}, \mathrm{CDCl}_{3}\right): \delta 2.0(1 \mathrm{H}, \mathrm{s}$, $\mathrm{C} \equiv \mathrm{CH}), 2.6\left(2 \mathrm{H}, \mathrm{m}, \mathrm{CH}_{2}-\mathrm{C} \equiv \mathrm{C}\right), 4.3\left(2 \mathrm{H}, \mathrm{m}, \mathrm{CH}_{2}-\mathrm{OC}(\mathrm{O})\right), 5.8\left(1 \mathrm{H}, \mathrm{d}, \mathrm{J}=10 \mathrm{~Hz}, \mathrm{C}(\mathrm{H}) \underline{\mathrm{H}}_{\mathrm{cis}}=\mathrm{C} \underline{\mathrm{H}}-\right.$ $\left.\mathrm{CO}_{2}\right), 6.1\left(1 \mathrm{H}, \mathrm{dd}, \mathrm{J}=10\right.$ and $\left.17 \mathrm{~Hz}, \mathrm{CH}_{2}=\mathrm{CH}-\mathrm{CO}_{2}\right), 6.4\left(1 \mathrm{H}, \mathrm{d}, \mathrm{J}=17 \mathrm{~Hz}, \mathrm{C}(\mathrm{H}) \underline{\mathrm{H}}_{\text {trans }}=\mathrm{CH}-\mathrm{CO}_{2}\right)$. Macromonomer 31. $0.24 \mathrm{mg}(1.5 \mathrm{mmol})$ of 5-azidooxepan-2-one 10 was transferred into a glass reactor containing $3 \mathrm{ml}$ of THF. $1.16 \mathrm{mg}(1.5 \mathrm{mmol})$ of alkyn end-capped PEO 30, $30 \mathrm{mg}(1.5$ $\mathrm{mmol})$ of $\mathrm{CuI}$ and $15 \mathrm{mg}(1.5 \mathrm{mmol})$ of $\mathrm{NEt}_{3}$ were then added, and the solution was stirred at $35^{\circ} \mathrm{C}$. After $2 \mathrm{~h}$, the solution was concentrated in vacuo, transferred into $50 \mathrm{ml}$ of diethylether and kept at $-20^{\circ} \mathrm{C}$ overnight. The macromonomer was filtrated and dried in vacuo (Yield $=95$ \%). ${ }^{1} \mathrm{H}$ NMR (250 MHz, $\left.\mathrm{CDCl}_{3}\right) \delta$ 2.0-2.5 (4H, massif, $2 \mathrm{C}_{2}-\mathrm{CH}\left(\right.$ triazole)- $\left.\underline{\mathrm{C}}_{2}\right), 2.7-2.8(3 \mathrm{H}$, massif, O-CO-CH${ }_{2} \mathrm{CH}_{2}$-triazole, $\mathrm{CH}_{2}$ and $\left.\mathrm{C}(\mathrm{H}) \underline{\mathrm{H}}-\mathrm{CO}_{2}\right), 2.9\left(1 \mathrm{H}, \mathrm{m}, \mathrm{C}(\mathrm{H}) \mathrm{H}-\mathrm{CO}_{2}, 3.0(2 \mathrm{H}, \mathrm{m}\right.$, $\mathrm{C}_{2}-\mathrm{CH}_{2}$-triazole), $3.3\left(3 \mathrm{H}, \mathrm{s}, \mathrm{CH}_{3} \mathrm{O}\right), 3.6$ (n x $\left.4 \mathrm{H}, \mathrm{s}, \mathrm{O}-\mathrm{C}_{2} \mathrm{C}_{2}-\mathrm{O}\right), 4.2\left(2 \mathrm{H}, \mathrm{m}, \mathrm{CH}_{2}-\mathrm{C}_{2}-\mathrm{O}-\right.$ CO-CH $\left.{ }_{2}\right) 4.3\left(1 \mathrm{H}, \mathrm{m}, \mathrm{C}(\mathrm{H}) \underline{\mathrm{H}}-\mathrm{OCO}-\mathrm{CH}_{2}\right), 4.5\left(1 \mathrm{H}, \mathrm{m}, \mathrm{HC}(\mathrm{H}) \underline{\mathrm{H}}-\mathrm{OCO}-\mathrm{CH}_{2}\right), 4.8(1 \mathrm{H}, \mathrm{m}, \mathrm{CH}-$ triazole) $7.5\left(1 \mathrm{H}, \mathrm{s}\right.$, triazole). IR $\delta\left(\mathrm{cm}^{-1}\right): 1734(\mathrm{C}=\mathrm{O}), 1646$ (triazole).

\section{Supplementary Information Available}

The assignments of the ${ }^{1} \mathrm{H}$ and ${ }^{13} \mathrm{C}$ NMR chemical shifts were confirmed by two-dimensional ${ }^{1} \mathrm{H}$, ${ }^{13} \mathrm{C}$ Heteronuclear Multiple Quantum Coherence (HMQC) spectrum, which are provided as supplementary information.

\section{Acknowledgements}

The authors are much indebted to the "Belgian Science Policy" for financial support in the frame of the "Interuniversity Attraction Poles" Programme (PAI V/03): Supramolecular Chemistry and Supramolecular Catalysis. Ph. L. is Research Associate by the belgian "Fonds National de la Rechecherche Scientifique". R. Riva thanks the "Fonds pour la Formation à la Recherche dans l'Industrie et l'Agriculture" (FRIA) for a fellowship.

\section{References and Notes}

1. Lecomte, P.; Jérôme, R. In Encyclopedia of Polymer Science and Technology, $3^{\text {rd }}$ Edn., John Wiley and Sons, Inc., 2004; Vol. 11, pp 547-565.

2. Jérôme, R.; Lecomte, $\mathrm{Ph}$. In Biodegradable polymers for polymer industrial applications Smith, R., Ed.; Woodhead Publishing Ltd, 2005, pp 77-106. 
3. Lecomte, Ph.; Riva, R.; Schmeits, S.; Rieger, J.; Van Butsele, K.; Jérôme, Ch.; Jérôme, R. Macromol. Symp. 2006, 240, 157.

4. Lou, X.; Detrembleur, Ch.; Jérôme, R. Macromol. Rapid Commun. 2003, 24161.

5. Mecerreyes, D.; Humes, J.; Miller, R. D.; Hedrick, J. L.; Lecomte, Ph.; Detrembleur, Ch., Jérôme, R. Macromol. Rapid Commun. 2000, 21, 779.

6. Mecerreyes, D.; Miller, R. D.; Hedrick, J. L.; Detrembleur, Ch.; Jérôme, R. J. Polym. Sci., Polym. Chem. 2000, 38, 870.

7. Li, H.; Jérôme, R.; Lecomte, Ph. Polymer 2006, 47, 8406.

8. Parrish, B. ; Breitenkamp, R. ; Emrick, T. J. Am. Chem. Soc. 2005, 127, 7404.

9. Trollsas, M.; Lee V. Y.; Mecerreyes, D.; Löwenhielm, D.; Möller, M.; Miller, R. D.; Hedrick, J. L. Macromolecules 2000, 33, 4619.

10. Liu, M.; Vladimirov, N. ; Fréchet, J.-M. Macromolecules 1999, 32, 6881.

11. Yu, X.-h. ; Feng, J. ; Zhuo, R.-X. Macromolecules 2005, 38, 6244.

12. Trollsas, M.; Löwenhielm, P.; Lee, V. Y.; Möller, M.; Miller, R. D.; Hedrick, J. L. Macromolecules 1999, 32, 9062.

13. Stassin, F.; Halleux, O.; Dubois, Ph.; Detrembleur, Ch.; Lecomte, Ph.; Jérôme, R., Macromol. Symp. 2000, 153, 27.

14. Gautier, S.; D’aloia, V.; Halleux, O. ; Mazza, M. ; Lecomte, Ph. ; Jérôme, R. J. Biomater. Sci., Polym. Ed. 2003, 14, 63.

15. Leemhuis, M.; van Nostrum, C. F.; Kruijtzer, A. W.; Zhong, Z. Y.; ten Breteler, M. R.; Dijkstra, P. J.; Feijen, J.; Hennink, W. E. Macromolecules 2006, 39, 3500.

16. Saulnier B.; Coudane, J.; Garreau, H. ; Vert ; M. Polymer 2006, 47, 1921.

17. Tian, D.; Dubois, Ph.; Jérôme, R. Macromolecules 1997, 30, 2575.

18. Tian, D.; Dubois, Ph.; Grandfils, Ch.; Jérôme, R. Macromolecules 1997, 30, 406.

19. Latere, J.-P.; Lecomte, Ph.; Dubois, Ph., Jérôme, R. Macromolecules 2002, 35, 7857.

20. Detrembleur, C.; Mazza, M; Halleux, O.; Lecomte, Ph.; Mecerreyes, D.; Hedrick, J. L.; Jérôme, R. Macromolecules 2000, 33, 14.

21. Mecerreyes, D.; Atthof, K. A.; Boduch, J. L.; Hedrick, J. L. Macromolecules 1999, 32, 5175.

22. Pitt, C. G.; Gu, Z.-W.; Ingram, P.; Hendren, R. W. J. Polym. Sci., Polym. Chem. 1987, 25, 955.

23. Rostovstev, V. V.; Green G. L.; Fokin V. V.; Sharpless, K. B. Angew. Chem. Int. Ed. 2002, 41, 2596.

24. Kolb H. C.; Finn M. G.; Sharpless, K. B. Ang. Chem. Int. Ed. 2001, 40, 2004.

25. Riva, R.; Schmeits, S.; Stoffelbach, F.; Jérôme, Ch.; Jérôme, R.; Lecomte, Ph. Chem. Commun. 2005, 5334.

26. Riva, R.; Schmeits, S.; Jérôme, C.; Jérôme, R.; Lecomte, Ph. Macromolecules 2007, 40, 796.

27. Lou, X.; Detrembleur, Ch.; Lecomte, Ph.; Jérôme, R. J. Polym. Sci., Polym. Chem. 2002, 40, 2286. 
28. Mecerreyes, D.; Lee, V.; Hawker, C. J.; Hedrick, J. L.; Wursch, A.; Volksen, W.; Magbitang, T.; Huang, E.; Miller, R. D. Adv. Mater. 2001, 13, 204.

29. Li, H.; Debuigne, A.; Jérôme, R.; Lecomte, Ph. Angew. Chem. Int. Ed. 2006, 45, 2264.

30. Rieger, J.; Dubois, P.; Jérôme, R.; Jérôme, C. Langmuir 2006, 22, 7471.

31. Rieger, J.; Passirani, C.; Benoit, J.-P.; Van Butsele, K.; Jérôme, R.; Jérôme, C. Adv. Funct. Mater. 2006, 16, 1506.

32. Rieger, J.; Bernaerts, K. V.; Du Prez, F. E.; Jérôme, R.; Jérôme C. Macromolecules 2005, 37, 9738.

33. Bräse, S.; Gil, C.; Knepper, K.; Zimmerman, V. Angew. Chem. Int. Ed. 2005, 44, 5188.

34. Luedtke, A. E.; Timberlake, J.W. J. Org. Chem. 1985, 50, 268. 